\title{
Understanding hydrological processes at a remote mountainous continuous permafrost watershed in a changing environment
}

\author{
$\underline{\text { N. Nesterova }}^{\mathrm{a}, \mathrm{b}}$, O. Makarieva ${ }^{\mathrm{a}, \mathrm{c}}$ and D. A. Post ${ }^{\mathrm{d}}$ \\ ${ }^{a}$ Saint Petersburg State University, Institute of Earth Sciences, St. Petersburg, Russia, ${ }^{b}$ State Hydrological \\ Institute, St. Petersburg, Russia, ${ }^{c}$ Melnikov Permafrost Institute, Yakutsk, Russia, ${ }^{d}$ CSIRO, Canberra, \\ Australia \\ Email: nnesterova1994@gmail.com
}

\begin{abstract}
This research assesses the possibility of using unique special observations data at the SuntarHayata station in Eastern Siberia (it was operating from 1957-1959 under the program of the International Geophysical Year) to develop and apply methods for modelling hydrological processes in the permafrost zone under conditions of poor information content to identify flow changes and understand the causes of their occurrence.

In the course of the work, the results of special observations were analysed, the parameters of the hydrological model, Hydrograph, characterizing the landscapes of the Eastern Siberia, were developed. The parameters were verified in the modelling of state variables at the Suntar River basin $\left(7680 \mathrm{~km}^{2}\right)$ and the modelled streamflow compared with the observed values (1957-1964). The results of the simulation were found to be satisfactory. At the next stage, the water balance and hydrographs were simulated for watersheds over the period 1966-2012. The results of the simulation are satisfactory too. It allows us to conclude that the Hydrograph model can reproduce the processes occurring in the catchment area allowing it to be used in the flow modelling of the study area.
\end{abstract}

To study the possibility of modeling the observed flow changes, the flow simulation for the period 1966-2012 was carried out. Significant increasing trends in simulated runoff were seen in May - 11.3 $\mathrm{mm}$ or $118 \%$, in September $-10.2 \mathrm{~mm}$ or $38.1 \%$, in October - $1.3 \mathrm{~mm}$ or $33.3 \%$ and in November $0.35 \mathrm{~mm}$ or $35.9 \%$. These trends are comparable to trends seen in the observed flow values.

The simulation confirmed the theory that runoff changes are due to an increase in the proportion of liquid precipitation during the transition months. The liquid precipitation increased by an average of $13.6 \mathrm{~mm}$ for the Suntar River basin, which is similar to to the observed streamflow value trend in September of about $10 \mathrm{~mm}$. Thus, the use of modelling methods can be a reliable tool for predicting runoff changes in permafrost. The method can be used to study the causes of runoff and variable state changes in other basins in the

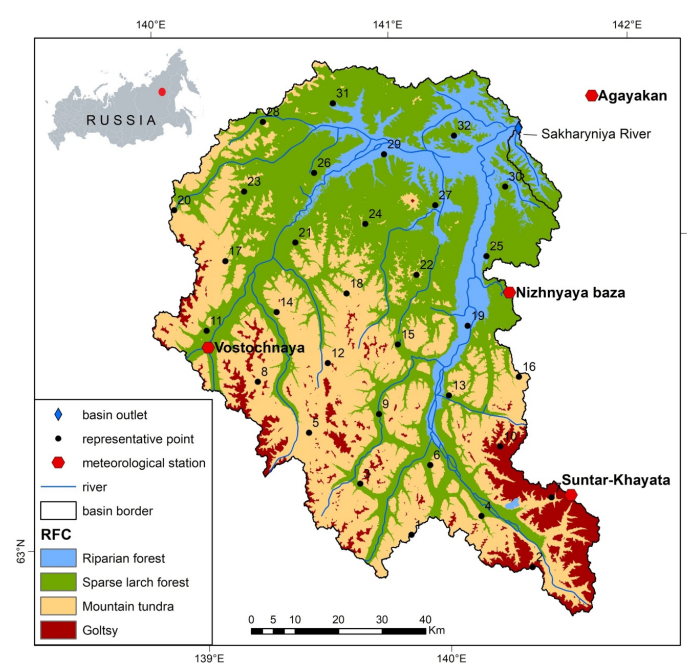

Figure 1. The Suntar River basin permafrost environment.

Keywords: Hydrograph model, parametrization, runoff formation processes, precipitation, climate change 
Nesterova et al., Understanding hydrological processes at a remote mountainous continuous permafrost watershed in a changing environment

\section{INTRODUCTION}

The terrestrial Arctic is characterized by severe climate and permafrost as well as permafrost-related processes, such as a seasonally dynamic active layer, ground ice, aufeis, rock glaciers, poor connectivity between surface and ground water, etc. In places, a mountainous relief results in enormous spatial and temporal heterogeneity of environmental conditions (Viviroli et al., 2011) including permafrost distribution and properties. Permafrost is warming (Romanovsky et al., 2010) and many cryogenic processes are activated due to a shifting climate. Many Arctic and particularly mountainous river basins are poorly-studied and lack observational and experimental time series data (Hinzman et al., 2005; Viviroli et al., 2011). Analysis of limited observational data suggests that the Arctic river streamflow is changing (Rawlins et al., 2010; Tananaev et al., 2016; Makarieva et al. 2019) but the mechanisms of observed changes are not fully understood.

A recently published paper (Chernokulsky et al., 2019) presents data on changes in precipitation regime and intensity of liquid precipitation in Eurasia: a small, mostly insignificant increase in total precipitation is accompanied by a significant increase in the intensity of rainfall and an increase in the contribution of heavy rain in all regions of Russia, which directly contributes to the formation of dangerous hydrological phenomena such as flash floods. Thus, it is recognized that we need to develop new methods of calculation hydrological response under the conditions of climate change and anthropogenic impact (Maghsood et al., 2019).

The lack of streamflow data can partly be compensated for through hydrological modelling. Numerous studies of the possibilities of using hydrological modeling methods for calculating the different characteristics of runoff have been carried out, for example (Brocca et al., 2011). Models also help not only to determine flow characteristics, but also to follow changes in the environment and investigate their causes. Tornros and Menzel (2010) concluded that the decrease in runoff in the Haraa River basin was due to changes in the regional climate, and not due to increased water consumption using the conceptual model HBV-D based on calculations for the historical period (1990-2002). In Essaid and Hill (2014), on the contrary, modeling helped to expose the impact of land use on the hydrological regime and to study its change. The results illustrate the interdependence between: watershed and meadow hydrology; bedrock and meadow aquifers; and surface and groundwater flow through the meadow for the modeled scenarios (Essaid and Hill, 2014). Li et al. (2012) found that the impact of human activity is greater than climate change after 1972 using the SIMHYD hydrological model. Annual streamflow during the period $1972-2003$ was $79 \%$ of the baseline period (1952-1971). Models are also used for projections of future states of hydrological systems due to climate change (Kour et al., 2016). This makes it possible to use models in the socio-economic development of countries and in government management (Refsgaard, 2007.).

The purpose of this article is to study the possibility of using hydrological modelling methods to identify flow changes at remote mountainous continuous permafrost watersheds and to understand the causes of these changes.

\section{STUDY AREA, MODELLING METHOD AND VERIFICATION}

\subsection{Study area}

The Suntar river -at the mouth of the Sakharyniya river $\left(7680 \mathrm{~km}^{2}\right)$ was selected as the object of the study (Figure 1). These rivers belong to the Indigirka river basin and flow from the Suntar-Khayata Ridge. The high-altitude Suntar-Khayata station was operating in the Suntar river basin in 1957-1959 under the program of the International Geophysical Year. Glaciological, geomorphological, geocryological and hydrological observations were carried out (Grave et al., 1964). It was located at the altitude of $2067 \mathrm{~m}$ in a rocky talus landscape and the observations are unique for the high-mountain areas of Eastern Siberia and the North-East of Russia.

The average altitude of the Suntar river catchment is $1410 \mathrm{~m}$ a.s.l., peaking at $2794 \mathrm{~m}$ a.s.l. The studied territory is situated in the region of continuous permafrost, its thickness within the mountain ranges is about 400-600 m, and under river valleys $-200-300 \mathrm{~m}$. The climate of the region is extremely continental with altitudinal zonation and temperature inversions in the cold season. Average annual temperature is $-13.8,+6.4$ in July, and -28.0 in January at the Suntar-Hayata station (2068 m a.s.1.) for the period 1957-1964. The same values at the Agayakan meteorological station (776 m a.s.l.) for the period $1957-2012$ are $-14.1^{\circ} \mathrm{C},+17.5^{\circ} \mathrm{C}$ and $-39.6{ }^{\circ} \mathrm{C}$ correspondingly. 
Nesterova et al., Understanding hydrological processes at a remote mountainous continuous permafrost watershed in a changing environment

Daily air temperature and humidity, precipitation totals from weather stations of the standard hydrometeorological network within or nearby the basins were used as meteorological input for hydrological modelling. Four of them, Suntar-Khayata - $2068 \mathrm{~m}$ a.s.1., Nizhnyaya Baza - $1350 \mathrm{~m}$ a.s.1., Vostochnaya $1287 \mathrm{~m}$ a.s.1. and Agayakan - $776 \mathrm{~m}$ a.s.1., were used for the period 1957-1964 and two, Agayakan and Vostochnaya, for the period 1966-2012 (Figure 1 shows the locations of these stations).

The river is characterized by a high spring freshet and rainfall-derived summer-autumn floods. In winter, the studied rivers freeze completely. Maximum streamflow is observed in the summer months. Snow cover is formed in September. Usually a spring freshet begins in the third week of May. Average annual flow for the Suntar river is about $189 \mathrm{~mm}$, with a maximum recorded daily discharge of $1900 \mathrm{~m}^{3} / \mathrm{s}$ (1957-1964).

The study basin is situated in the forest-tundra and coniferous taiga. In high altitude areas, a rocky talus landscape ('goltsy' in Russian) and small glaciers are typical. The tundra landscape is characterized by a depressed layer of grass and moss. Most of the basin is covered by larch woodland with moss-lichen cover. In river valleys, grass-moss larch forest and swampy sparse growth forest are typical. Soil types at these landscapes are clayey podzol with partially decayed organic material underlain by frozen soil and bedrock.

\subsection{Modelling method}

The Hydrograph model is a distributed process-based hydrological modelling system (Vinogradov et al., 2011). It describes all components of the land hydrological cycle, including precipitation and its interception; snow accumulation and melt; evaporation from snow, soil, and vegetation cover; surface flow and infiltration; soil water dynamics and flow; heat dynamics and phase change in soil layers; underground flow formation, slope and channel flow transformation. The outputs are flow hydrographs, water balance and state variables of the soil of basin elements. The model can be run at time steps from minutes and hours to daily.

The concept of runoff elements used in the Hydrograph model for spatial discretization of basins is a key advantage of the modelling approach. The catchment area consists of runoff elements of different levels surface, soil and underground. The concept proposes the system of runoff elements characteristics, such as outflow time which include the time and intensity of outflow from elements, depending on the water storage (Vinogradov et al., 2011). The Hydrograph model has been successfully applied to simulate the river runoff formation in cold regions with a lack of ground-based observational data (Vinogradov et al., 2011; Semenova et al., 2013).

Within the discretization procedure, the basin territory is divided into several conditionally homogeneous parts called runoff formation complexes (RFC). It is assumed that the characteristics of soil, vegetation, topography, and other components of the landscape are constant within each RFC, while the runoff formation process is uniform. The main parameters of the model are the physical properties of the landscapes that may be observed and quantified and are classified according to the types of soil, vegetation and other characteristics (Vinogradov et al., 2011). According to altitudinal zonation, the catchment of the Suntar river is divided into 4 RFCs: Goltsy (RFC \#1, is located at the altitude range 1900 to $2700 \mathrm{~m}$ a.s.1.), mountain tundra (RFC \#2, 1450-1900 m a.s.1.), sparse larch forest (RFC \#3, 1100-1450 m a.s.1.) and riparian forest at waterlogged soils (RFC \#4, 828-1100 m a.s.1.) (Grave et al., 1964).

The model requires the following atmospheric variables as its inputs: air temperature and humidity and the volume of precipitation. Annual average monthly temperature and air saturation deficit elevation gradients were estimated using the data from the Suntar-Khayata and Agayakan meteorological stations (the range of elevation is $1292 \mathrm{~m}$ ), they change from $+1.1^{\circ} \mathrm{C}$ and +0.01 mbar by $100 \mathrm{~m}$ elevation increase in January to $1.3{ }^{\circ} \mathrm{C}$ and $-0.35 \mathrm{mbar}$ by $100 \mathrm{~m}$ in June. The data of four meteorological stations (Suntar-Khayata, Nizhnyaya Baza, Vostochnaya and Agayakan) and the information of snow surveys at high mountain elevations (Grave, 1960) were used to analyse the distribution of precipitation at different altitudes for warm (May - August) and cold (September - April) periods of the year.

\subsection{Model verification}

The parametrization of the Hydrograph model was performed based on joint analysis of available field descriptions of ground hydrothermal regime and consistent patterns of runoff formation in typical landscapes. The parametrization of goltsy landscape (RFC \#1) was developed with the use of observational data from the Suntar-Khayata station (Grave, 1959; Grave, Koreisha, 1957; Koreisha, 1963). Assuming that runoff formation processes in mountainous regions of the Kolyma river upstreams and the Suntar river basin are similar, the parameters for RFC \#\#2-4 were adopted from (Semenova et al., 2013; Lebedeva et al., 2014), who assessed them based on detailed data from the Kolyma water-balance station (Makarieva et al., 2018). 
Nesterova et al., Understanding hydrological processes at a remote mountainous continuous permafrost watershed in a changing environment

During the verification period, we conducted the simulation of individual processes and compared the results with the available observations. As such, the comparison of simulated and observed values of snow depth and snow cover indicates that the model correctly describes snowmelt processes. Calculated values of temperature of the soil at various depths closely matched observed data with the largest discrepancies not exceeding $5{ }^{\circ} \mathrm{C}$. In addition, the results of soil thaw/freeze for the Suntar-Hayata site were also considered satisfactory.

The verification of daily flow simulation was carried out for the Suntar River basin for the period 1957-1964, using input meteorological data from four weather stations (Suntar-Khayata, Nizhnyaya Baza, Vostochnaya and Agayakan). The average and median Nash-Sutcliffe efficiency (NSE) for the Suntar River amounted to 0.75 in 1957-1964. Water balance components distribution for these periods are presented in Table 1 and the comparison of observed and calculated streamflow hydrographs - in Figure 2. Satisfactory results allow us to conclude that the Hydrograph model can reproduce the processes occurring in the catchment area and it can be used in the flow modelling of the study area.
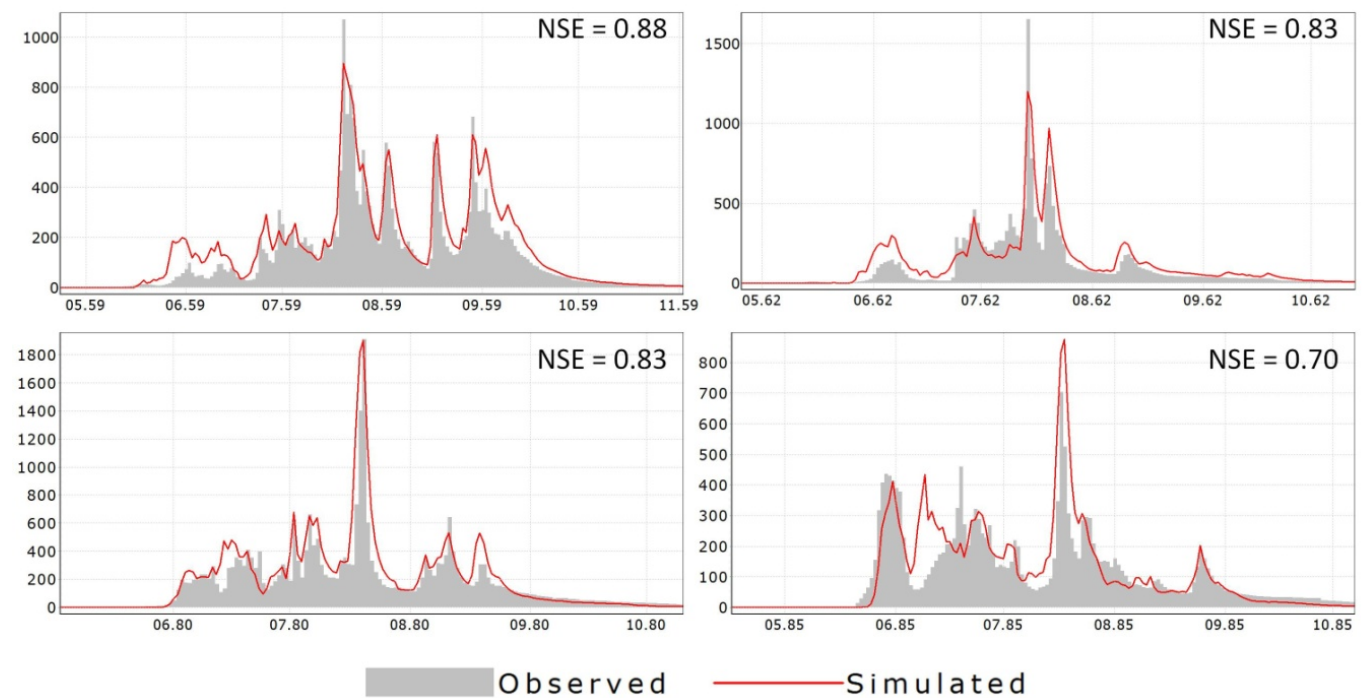

Figure 2. Observed and simulated hydrograph at the Suntar River, $\mathrm{m}^{3} / \mathrm{s}$

Table 1. The results of streamflow modelling, the Suntar River

\begin{tabular}{|l|l|l|l|l|l|l|l|l|}
\hline Period & N & Yo & Ys & P & E & Qo & Qs & NSE (av, med, max/min) \\
\hline $1957-1964$ & 4 & 180 & 199 & 344 & 143 & 1659 & 1200 & $0.75,0.75,0.88 / 0.40$ \\
\hline $1966-2012$ & 2 & 180 & 203 & 332 & 127 & 1910 & 1905 & $0.58,0.67,0.87 /-0.90$ \\
\hline
\end{tabular}

where $\mathrm{N}$ - number of meteorological stations used; Yo and Ys - observed and simulated average annual runoff, mm; P - precipitation, $\mathrm{mm}$; E - evaporation, mm; Qo and Qs - maximum observed and simulated flow, $\mathrm{m}^{3} / \mathrm{s}$; NSE av, med - the average and median NSE; max and min - the maximum and minimum value of yearly NSE.

\section{RESULTS OF STREAMFLOW CHANGE MODELLING}

In Arctic catchments, the most important task in the context of climate change is to study the change in hydrology. In general, river streamflow in Northern Eurasia and North America is increasing (Shiklomanov and Lammers, 2014). To study recent flow changes, continuous runoff modelling with daily temporal resolution was carried out using the verified parameters for the Suntar River for the period 1966-2012 using data from two meteorological stations (Vostochnaya and Agayakan). Comparison with observed streamflow data showed that the average and median NSE for the period 1966-2012 is lower than for the period 19571964 (average 0.58 , median 0.67 with maximum and minimum yearly values of 0.88 and -0.90 , respectively) (Table 1). We attribute this decrease of efficiency to the lack of meteorological data in the second period, with only two stations operating instead of 4 . Another possible cause may be hydrological changes in the second period, as the model is not only attempting to reproduce the hydrological response, but also the observed changes in hydrological response. Overall, despite some overestimation of streamflow during the spring flood period (Figure 2), the calculated streamflow hydrographs match the observed ones quite satisfactorily, both in the shapes of the hydrograph and absolute discharge values.

At the next step, time series of observed and simulated monthly flow characteristics were evaluated for stationarity, in relation to the presence of monotonic trends, with Mann-Kendall and Spearman rank- 
Nesterova et al., Understanding hydrological processes at a remote mountainous continuous permafrost watershed in a changing environment

correlation tests, at the significance level of $\mathrm{p}<0.05$ (Mann, 1945; Kendall, 1975). The Pettitt's test (Pettitt, 1979) was applied to look for the presence of a change point in the time series at $p \leq 0.05$. Note that the trends are presented for the entire period of observations, and not for the period after the change point was identified, as there can be multiple trends within the period of observations.

The analysis of observed monthly streamflow data in the Suntar River has shown the presence of statistically significant $(\mathrm{p}<0.05)$ positive trends in the May and autumn periods. The values of increasing trends are the following: in May - $6.8 \mathrm{~mm}$ or $103 \%$, in September $-9.9 \mathrm{~mm}$ or $49 \%$, in October $-3.3 \mathrm{~mm}$ or $70 \%$ and in November $-0.43 \mathrm{~mm}$ or $52 \%$ (Makarieva et al., 2019). The significant trends in simulated streamflow modelled here occur in May $-11.3 \mathrm{~mm}$ or $118 \%$, in September $-10.2 \mathrm{~mm}$ or $38.1 \%$, in October $-1.3 \mathrm{~mm}$ or $33.3 \%$ and in November $-0.35 \mathrm{~mm}$ or $35.9 \%$. Generally, the simulated trends are similar to trends in the observed flow values especially in September, when the difference does not exceed $11 \%$. Most hydrological stations in the Indigirka and Yana River Basin show observed change points in the spring period around 1966 (Makarieva et al., 2019). This is similar to the results here, where the change point in simulated flow occurred in 1965. The change point in the autumn season coincides with the observed data and refers to the period 1993-1996.

According to Makarieva et al. (2019), there is a decrease in precipitation in the winter of 8 to $13 \mathrm{~mm}$ and the absence of significant change in other seasons. The rise of annual air temperature of $+2.0^{\circ} \mathrm{C}$ led to an increase in the amount of liquid precipitation in September by about $12 \mathrm{~mm}$. It is hypothesized in that paper that the phase state of precipitation is the main factor affecting the increase of low flows of the studied rivers. Figure 3 shows the combined graphs of the flow, the total precipitation and liquid precipitation in September for the Suntar River basin. The scheme of high-altitude precipitation distribution at the catchment scale made it possible to estimate changes in precipitation characteristics for the entire basin based on the Vostochnaya weather station $(1288 \mathrm{~m})$ data. The increase in liquid precipitation at the Vostochnaya station in September is $12.9 \mathrm{~mm}$. The distribution of precipitation with height was taken according to the dependencies revealed at different altitudes for warm and cold periods as the result of the current study. Precipitation amount for each calculated point within the basin is assessed according to those dependencies based on its elevation and interpolated daily sums of precipitation are normalized. The modeling supports the theory about the increase of liquid precipitation in the catchment. The analysis showed that the share of liquid precipitation increased by an average of $10 \%$ or $13.6 \mathrm{~mm}$ within the Suntar River basin, which corresponds to the observed streamflow value trend in September which is about $10 \mathrm{~mm}$.
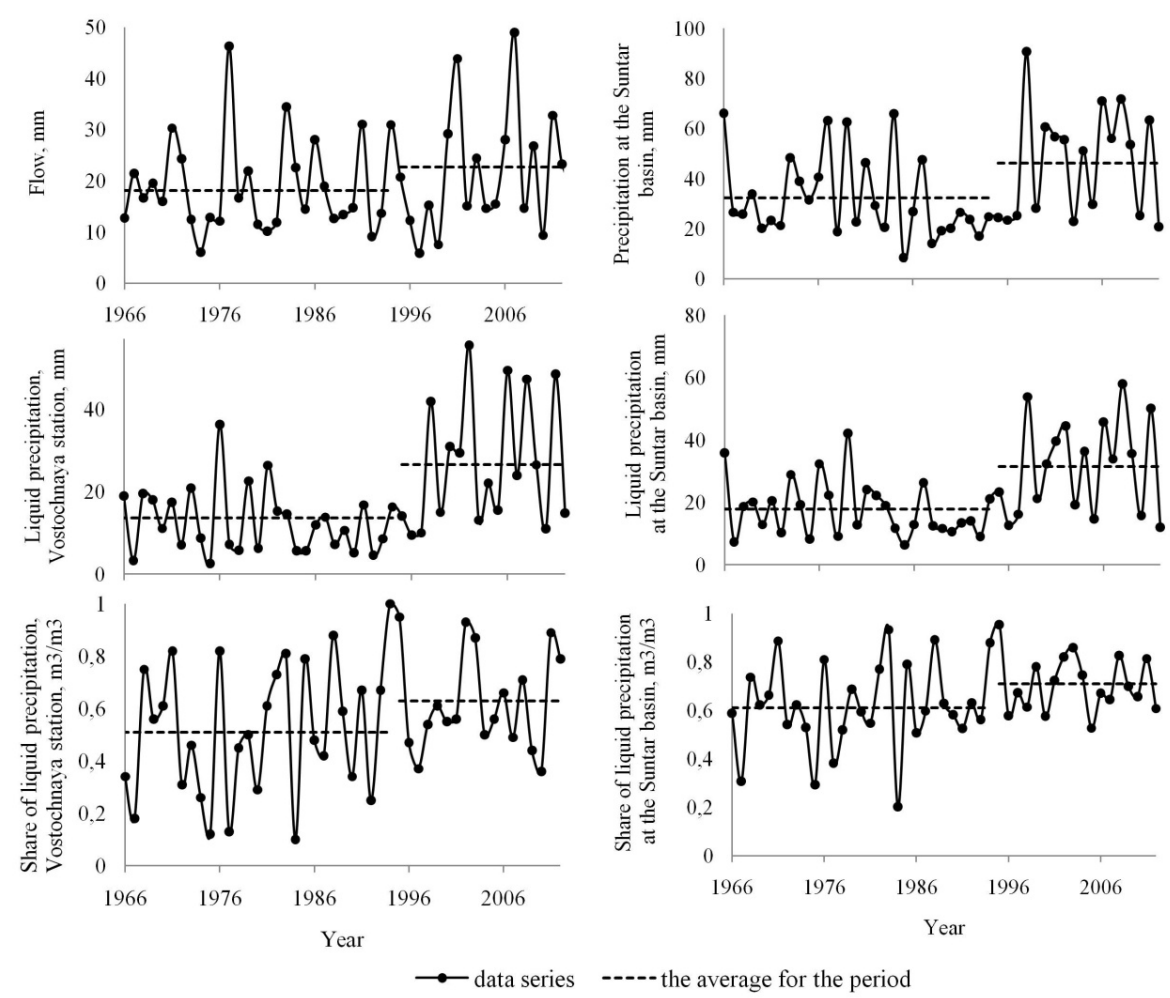

Figure 3. Graphs of hydrometeorological characteristics changes at the Suntar river basin 
Nesterova et al., Understanding hydrological processes at a remote mountainous continuous permafrost watershed in a changing environment

\section{CONCLUSION}

Detailed regional studies are crucial for understanding hydrological process in mountainous and permafrost regions with important implications for ungauged river basins (Viviroli et al., 2011). Walvoord and Kurylyk (2016) highlighted the importance of linking simulations with field observations of permafrost and hydrologic processes and developing improved representation of hydraulic properties of frozen soils. In this paper, the data of special studies from the Suntar-Hayata station during the 1957-1964 allowed us to develop the model parameters and verify them through application to a subsequent period. The satisfactory state variables and water balance results of the modelling shows that the model adequately describes the processes within the mountainous catchment Suntar River basin in the zone of continuous permafrost.

Continuous runoff modelling for the period 1966-2012 allowed us to identify the trends in flow changes. The results of comparing the values and the change point of the calculated trend with the observed trends were accepted as satisfactory.

There are several main hypotheses most often discussed in the context of increasing river discharge in the Arctic regions: 1) the transformation of the mechanisms of the underground supply as a result of permafrost degradation (Romanovsky et al., 2010; Walwoord et al., 2012), 2) melting of glaciers (Liljedahl et al., 2017) or 3) an increase in precipitation (Dyurgerov, Carter, 2004). Results of modeling in this work allowed us to confirm the assumption stated in Makarieva et al. (2019), associated with the reason for the runoff change being due to the increase in the proportion of liquid precipitation during the autumn transitional months.

The hydrological model, Hydrograph, has been shown to be applicable in the task of understanding the processes, identifying the response of the catchment to climate change and can be used to predict and assess future changes in runoff and state variables in catchments in the zone of continuous permafrost.

\section{ACKNOWLEDGMENTS}

The reported study was funded by RFBR, project number 19-35-90090.

\section{REFERENCES}

Brocca, L., Melone, F. and Moramarco, T. (2011). Distributed rainfall-runoff modelling for flood frequency estimation and flood forecasting. Hydrological processes, 25(18), 2801-2813, https://doi.org/10.1002/hyp.8042.

Chernokulsky, A. (2019). Observed changes in convective and stratiform precipitation in Northern Eurasia over the last five decades, Environmental Research Letters, 14045001.

Dyurgerov, M. B., and Carter, C. L. (2004). Observational evidence of increases in freshwater inflow to the Arctic Ocean, Arctic Antarctic and Alpine Research, 36 (1), 117-122, doi:10.1657 - 1523-0430(2004)036.

Essaid, H. I., and Hill, B. R. (2014). Watershed-scale modeling of streamflow change in incised montane meadows, Water Resources Research, 50, doi:10.1002/2013WR014420.

Grave, N.A. (1959). Prior report on heat and moisture regimes of soil and rocks and heat exchange between them, 1958, the site of Suntar-Khayata, V.A. Obruchev Institute for Permafrost Studies of the Academy of Sciences, North-West branch, Yakutsk.

Grave, N.A., Gavrilova, M.K., Gravis, G.F., Katasonov, E.M., Kliukin, N.K., Koreisha, G.F., Kornilov, B.A. and Chistotinov, L.V. (1964). Freezing of the ground surface and glaciation of the Suntar-Hayat Range (Eastern Yakutia). Science, 141

Grave, N.A. and Koreisha, M.M. (1957). Interim scientific report on the work of the mountainous SuntarKhayata glaciological and geocryological Station (program 3 IHY), 1957, V.A. Obruchev Institute for Permafrost Studies of the Academy of Sciences, North-West branch, Yakutsk.

Hinzman, L. D., Bettez, N. D., Bolton, W. R., Chapin, F. S., Dyurgerov, M. B., Fastie, C. L. and Yoshikawa, K. (2005). Evidence and Implications of Recent Climate Change in Northern Alaska and Other Arctic Regions. Climatic Change, 72(3), 251-298. doi:10.1007/s10584-005-5352-2.

Kendall, M. G. (1975). Rank Correlation Methods - Griffin, London.

Koreisha, M.M. (1963). Materials of Glaciological Investigation. Suntar- Khayata, Institute for Permafrost Studies of the Academy of Sciences, USSR, The International Geophysical Year, 1957-1958-1959

Kour, R., Patel, N., and Krishna, A. P. (2016). Climate and hydrological models to assess the impact of climate change on hydrological regime: a review. Arabian Journal of Geosciences, 9(9). doi:10.1007/s12517-016-2561-0.

Lebedeva, L., Semenova (Makarieva), O. and Vinogradova, T. (2014). Simulation of Active Layer Dynamics, Upper Kolyma, Russia, using the Hydrograph Hydrological Model. Permafrost and Periglacial Processes. 25 (4), 270-280 DOI: 10.1002/ppp.1821. 
Nesterova et al., Understanding hydrological processes at a remote mountainous continuous permafrost watershed in a changing environment

Li, C., Yu, F., Liu, J. and Ni, C. (2012). Quantitative research of factor contributions on streamflow change using hydrological modeling. Proceedings of the 2nd International Conference on Remote Sensing, Environment and Transportation Engineering (RSETE 2012), 2035-2054.

Liljedahl, A. K., Gädeke, A., O’Neel, S., Gatesman, T. A., and Douglas, T. A. (2017). Glacierized headwater streams as aquifer recharge corridors, subarctic Alaska. Geophysical Research Letters, 44, 6876-6885, https://doi.org/10.1002/2017GL073834.

Maghsood, F.F., Moradi, H., Massah Bavani, A.R., Panahi, M., Berndtsson, R. and Hashemi, H. (2019). Climate change impact on floodfrequency and source area in Northern Iran under CMIP5 scenarios. Water, 11 (2), 273, https://doi.org/10.3390/w11020273.

Makarieva, O., Nesterova, N., Lebedeva, L., and Sushansky, S. (2018).Water balance and hydrology research in a mountainous permafrost watershed in upland streams of the Kolyma River, Russia: a database from the Kolyma Water-Balance Station, 1948-1997. Earth System Science Data, 10, 689-710, https://doi.org/10.5194/essd-10-689-2018.

Makarieva, O., Nesterova, N., Post, D. A., Sherstyukov, A., and Lebedeva, L. (2019). Warming temperatures are impacting the hydrometeorological regime of Russian rivers in the zone of continuous permafrost. The Cryosphere, 13, 1635-1659, https://doi.org/10.5194/tc-13-1635-2019.

Mann, H. B. (1945). Nonparametric tests against trend. Econometrica, 13, 245-259.

Pettitt, AN (1979). A non-parametric approach to the change point problem. Applied Statistics, 28(2), 126135

Rawlins, M. A., Serreze, M. C., Schroeder, R., Zhang, X., and C. McDonald, K. (2009). Diagnosis of the record discharge of Arctic-draining Eurasian Rivers in 2007, Environmental Research Letters, 4, 045011, doi:10.1088/1748-9326/4/4/045011.

Refsgaard, J. (2007). Hydrological Modeling and River Basin Management. Phd thesis, Geological Survey of Denmark and Greenland, 90.

Romanovsky, V. E., Smith, S. L., and Christiansen, H. H. (2010). Permafrost thermal state in the polar Northern Hemisphere during the International Polar Year 2007-2009: A synthesis. Permafrost and Periglacial Processes, 21, 106-116, doi: 10.1002/ppp.689.

Semenova (Makarieva), O., Lebedeva, L. and Vinogradov, Yu. (2013). Simulation of subsurface heat and water dynamics, and runoff generation in mountainous permafrost conditions, in the Upper Kolyma River basin, Russia. Hydrogeology Journal, 21(1), 107-119 DOI:10.1007/s10040-012-0936-1.

Shiklomanov, A. I., and Lammers, R.B. (2014). River ice responses to a warming Arctic - recent evidence from Russian rivers. Environmental Research Letters, 9, 035008, doi: 10.1088/1748-9326/9/3/035008.

Tananaev, N. I., Makarieva, O. M., and Lebedeva, L. S. (2016). Trends in annual and extreme flows in the Lena River basin, Northern Eurasia, Geophysical Research Letters, 43, 20136, doi:10.1002/2016GL070796.

Tornros, T. and Menzel, L. (2010). Heading for knowledge in a data scarce river basin: Kharaa, Mongolia. In: Herrman A, Schumann S (eds) Status and perspectives of hydrology in Small Basins (Proceedings of the Workshop held at Goslar-Hahnenklee, Germany, 30 March- 2 April 2009). IAHS, 336, 270-275.

Vinogradov, Y. B., Semenova (Makarieva), O. M. and Vinogradova, T. A. (2011). An approach to the scaling problem in hydrological modelling: the deterministic modelling hydrological system. Hydrological Processes, 25, 1055-1073. doi: 10.1002/hyp.7901.

Viviroli, D., Archer, D. R., Buytaert, W., Fowler, H. J., Greenwood, G. B., Hamlet, A. F., Huang, Y., Koboltschnig, G., Litaor, M. I., López-Moreno, J. I., Lorentz, S., Schädler, B., Schreier, H., Schwaiger, K., Vuille, M., and Woods, R. (2010). Climate change and mountain water resources: overview and recommendations for research, management and policy. Hydrology and Earth System Sciences, 15, 471504, https://doi.org/10.5194/hess-15-471-2011.

Walvoord, M. A., Voss, C. I., and Wellman, T. P. (2012). Influence of permafrost distribution on groundwater flow in the context of climate-driven permafrost thaw: Example from Yukon Flats Basin, Alaska, United States. Water Resources Research, 48, W07524, https://doi.org/10.1029/2011WR011595.

Walvoord, M. A. and Kurylyk, B. L. (2016). Hydrologic Impacts of Thawing Permafrost-A Review. Vadose Zo.,15, 6. 